\title{
Aboriginal engravings in the southwest of Western Australia: analysis of the Kybra Site
}

\author{
Natalie R. Franklin \\ School of Social Science, University of Queensland \\ Brisbane, Queensland 4072, Australia. E-mail: Natalie.Franklinepa.pld gov au
}

\begin{abstract}
This paper presents an analysis of Aboriginal rock engravings in the far southwestern comer of Westem Australia that were first described by Clarke in 1983, the Kybra Site. Comprising engravings of predominantly animal tracks, particularly bird tracks, on flat tabular limestone pavements, the site appeared to extend the known range of a group of rock engravings known as the Panaramitee. Engraving sites of this tradition are widely distributed across Australia, and the Panaramitee has been represented as homogeneous at a continental level. A multivariate investigation using correspondence analysis and cluster analysis was undertaken comparing the Kubra Site with other engraving sites in Western Australia and elsewhere. The aim was to determine whether the Kvbra Site showed similarities with other Panaramitee engraving sites, and whether an explanatory framework, known as the Discontinuous Dreaming Network Model, could account for any similarities or differences identified. I found that the Western Australian sites are more different to each other than they are to other sites in eastern Australia, and reveal similarities with engravings in Cape York Peninsula, the Carpentaria region and central western Queensland. This finding fits well with the tenets of the Discontinuous Dreaming Network Model, which holds that the similarities between engraving sites across vast distances of Australia reflect the widespread links forged by Dreaming tracks and suggested by the trade and other social networks that sometimes spanned the continent.
\end{abstract}

\section{INTRODUCTION}

A major problem in the study of rock art around the world is the measurement and explanation of variation and similarities in paintings and engravings, sometimes over considerable distances. What is the significance of the variation detected, and how does one compare different sites? Multivariate analysis of different traits, particularly motif types, affords the ability to compare disparate sites over vast distances. The significance of any variability detected by multivariate analysis can then be explored.

Franklin (2004) proposed the Discontinuous Dreaming Network Model to explain the widespread similarities across the continent of a group of rock engravings known as the "Panaramitee style" (Maynard, 1979), and was supported by multivariate analysis (Franklin, 2004, see below). Named after the type-site in South Australia, the Panaramitee style consists of pecked engravings of macropod and bird tracks, human footprints, circles, dots, crescents, spirals, radiate designs and only a small proportion of figurative motifs other than tracks. This style was claimed to be homogeneous at a continental level in terms of technique, form and motif proportions (Maynard, 1979). The Discontinuous Dreaming Network
Model suggested that the similarities between engraving sites across vast distances of Australia reflected the widespread links forged by Dreaming tracks and suggested by the trade and other social networks that sometimes spanned the continent. Dreaming tracks have been regarded as particularly significant in Aboriginal cosmology and land ownership (e.g. Chatwin, 1987; David, 2002; Elkin, 1934; Gunn, 1997, 2003; Layton, 1992; Morphy, 1983; Moyle, 1983; Munn, 1973; Spencer and Gillen, 1938; Strehlow, 1978; Sutton, 1988, 1990). Dreaming tracks reflect the activities of the Dreamtime ancestors during the creative era as they emerged from the earth and travelled across the country along lengthy tracks or circled within more narrowly defined regions. Dreaming tracks sometimes covered considerable distances across the continent (e.g. Sutton, 1990), frequently extending across group boundaries, facilitating meetings between local groups and travelling groups for gift exchange and rituals associated with the myth relevant to the track. The use of similar motifs across vast areas at sites related to particular Dreamings is well documented (e.g. Ross, 1997), and suggested that the shared understanding of motif forms provided a means for negotiating the rights and obligations of travellers along the tracks. The repetition of 


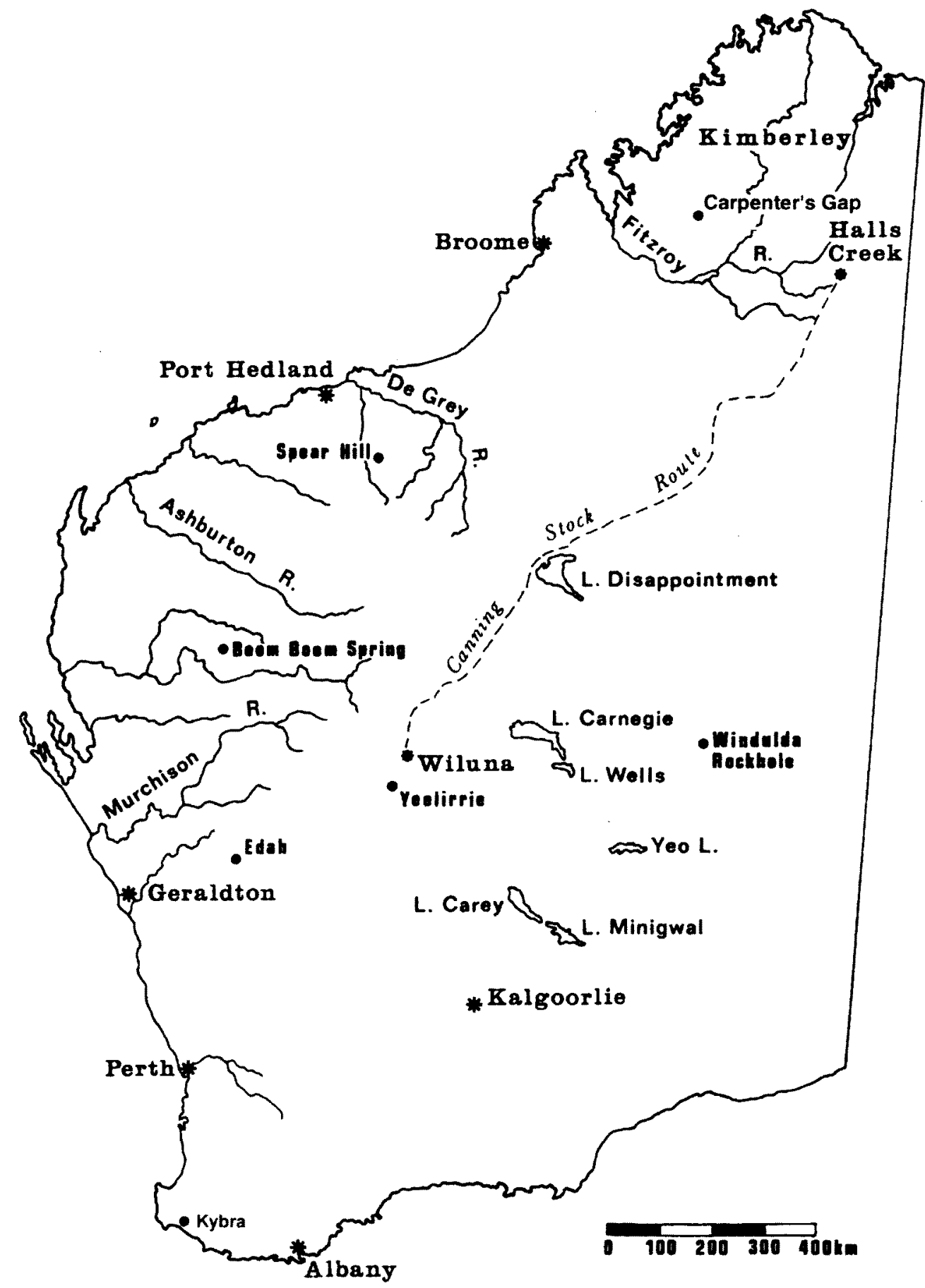

Figure 1 Map of Western Australia showing engraving sites mentioned in the text, and the location of other major rock art sites and regions in the State (after Franklin 2004: Fig. 3:9).

motifs between regions implied a shared knowledge that assured travellers of their right to move through the territory and which established an affilial relationship between the owners and the travellers. It is therefore not surprising that Dreaming tracks also frequently correlated with the trade routes documented in recent times (Ross, 1997), suggesting that both formed a means for the interaction of people across the landscape, and for the diffusion of similar motifs across vast areas.

The use of nonfigurative motifs (such as those found in the Panaramitee) in symbolic systems also helps to explain the persistence of the overall pattern of similarity between engraving sites identified in the multivariate analyses over possibly a prolonged period of time based on available chronological evidence (e.g. a minimum age of 13,000 years obtained for buried engravings at the Early Man site in the Laura region, Rosenfeld, 1981a) and the continued use of Panaramitee-type motifs in recent Aboriginal artistic systems (e.g. Anderson and Dussart, 1988). The potential for nonfigurative motifs 

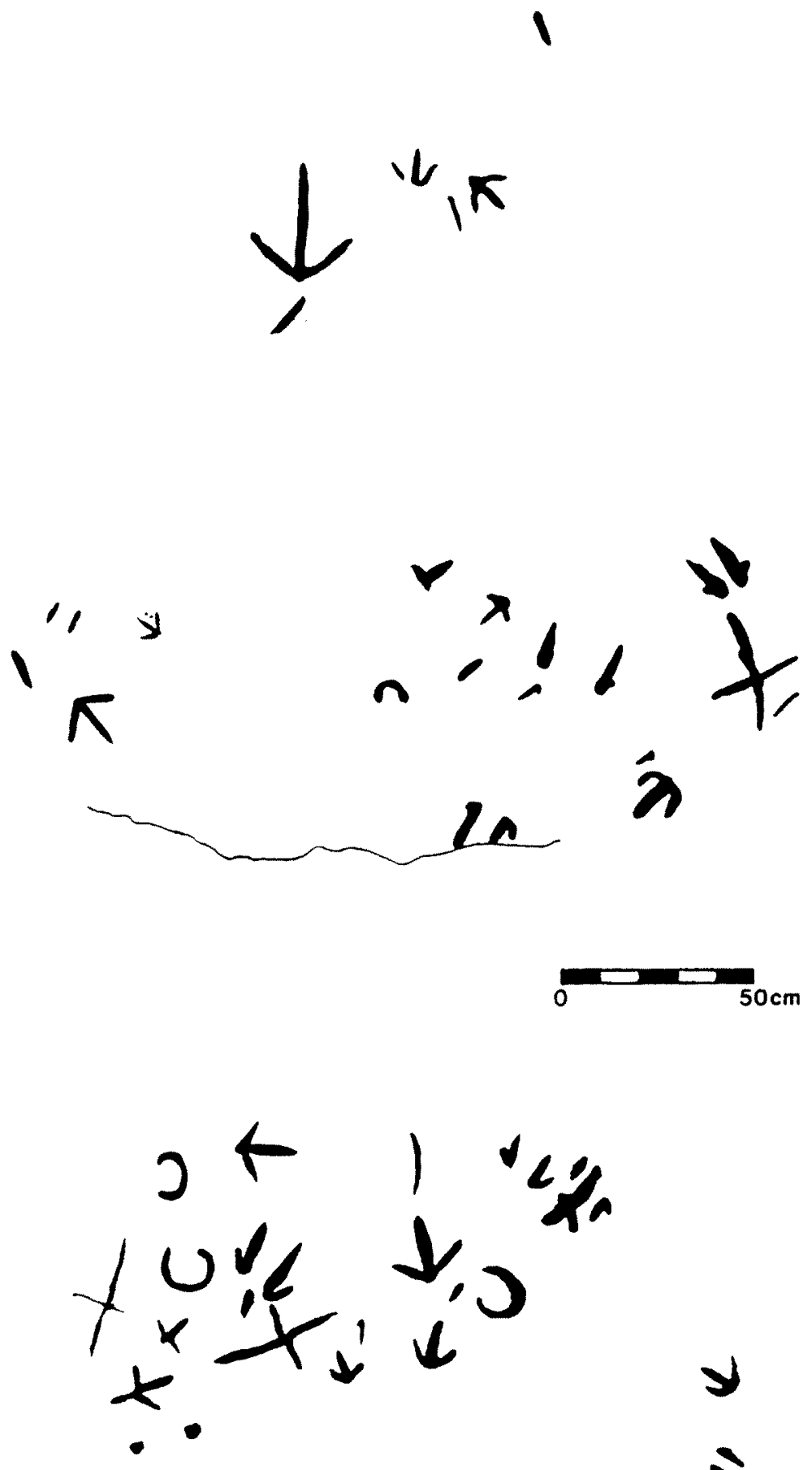

Figure 2 Examples of the rock engravings at the Kybra Site, southwestern Australia (after polythene tracings, Franklin, 2004: Fig. 3:10).

to have a range of different discontinuous meanings, ie., there may be a range of different meanings for a single motif (Munn, 1966), suggests it is possible that the meanings of motifs might have changed over time, while the morphology of the motifs might not. This possibility is allowed for by the extreme simplicity of motifs in the Panaramitee.

In 1983, J. Clarke reported rock engravings in the far southwestern corner of Western Australia (Department of Indigenous Affairs, Site No. S1786; Clarke, 1983; Figure 1), the Kybra site. Recorded rock art sites are relatively sparse in this part of Australia (Dortch, 1976, 1980; Hallam, 1971, 1972; Merrilees et al., 1973; Morse, 1984; Serventy, 1952; Webb and Gunn, 2004), and Kybra is one of the few rock engraving sites currently known. There are also few references to the forms of artistic expression at the time of European contact in this part of the continent (Caroline Bird, pers. comm.). Even so, there appears to have been a substantial body of mythology (Berndt, 1973; Hallam, 1972, $1974 a, b, 1979)$, and ochre was traded into the 
Table 1 Percentages of motifs at two of the Panaramitee tradition sites in Western Australia (after Franklin 2004: Table 3:3)

\section{Motifs}

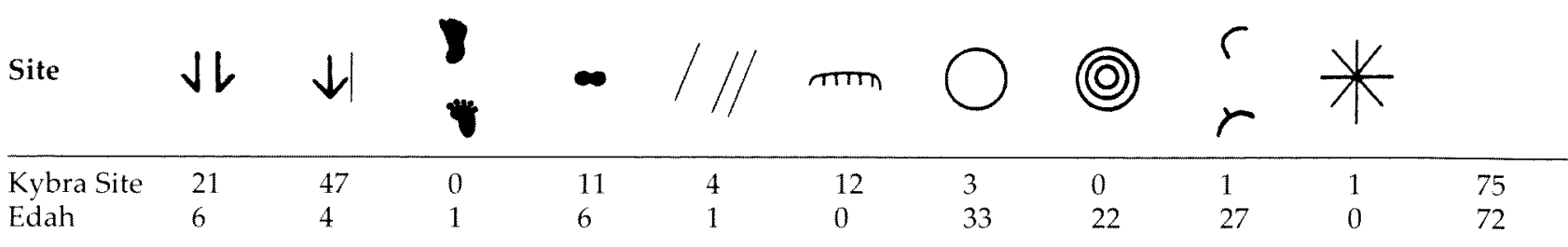

Table 2 Panaramitee sites included in the analyses, their abbreviations in Figures 4 and 5, and the source of the data. Unless otherwise stated, data are derived from tables of motif counts from each source.

\begin{tabular}{|c|c|c|}
\hline Site & Abbrev. & Source/Form of Data \\
\hline \multicolumn{3}{|l|}{ South Australia } \\
\hline Flinders Rangers & FR & Preiss (1962) \\
\hline Florina & $\mathrm{F}$ & \multirow{5}{*}{ Nobbs (1984) } \\
\hline Karolta 1 & K1 & \\
\hline Karolta 2 & K2 & \\
\hline Mt. Victor & MV & \\
\hline Oulnina & $\mathrm{O}$ & \\
\hline Rockholes & $\mathrm{R}$ & Gale (pers. comm.) \\
\hline Rowes Dam & $\mathrm{RD}$ & Nobbs (1984) \\
\hline Salt Creek & $\mathrm{SC}$ & Gale (pers. comm.) \\
\hline Tattawuppa & $\mathrm{T}$ & Nobbs (1984) \\
\hline Wharton Hill & WH & Gale (pers. comm.) \\
\hline Winnininnie 1 & Wi1 & \multirow{4}{*}{ Nobbs (1984) } \\
\hline Winnininnie 2 & Wi2 & \\
\hline Yunta & Y & \\
\hline Yunta Springs & YS & \\
\hline
\end{tabular}

\section{Western New South Wales}

\begin{tabular}{|c|c|c|}
\hline Sturt's Meadows & SM & Clegg (pers. comm.) \\
\hline \multicolumn{3}{|l|}{ Northern Territory } \\
\hline N'Dhala Gorge & NG & Forbes (pers. comm.) \\
\hline McArthur River & MR & $\begin{array}{l}\text { Haglund ( } 1975 \text {, pers. comm.) - drawing of engraved panel from } \\
\text { photographic montage }\end{array}$ \\
\hline \multicolumn{3}{|l|}{ Tasmania } \\
\hline Greens Creek & GC & Stockton (1977) - tracings of engravings, checked during personal fieldwork \\
\hline Mt. Cameron West & $\mathrm{MCW}$ & McCarthy (1969) - tracings of engravings, list of motifs \\
\hline Sundown Point & SP & Gunn (1981) - list of motifs, table of counts, sketch plan of site \\
\hline
\end{tabular}


Table 2 (cont.)

\begin{tabular}{|c|c|c|}
\hline Site & Abbrev. & Source/Form of Data \\
\hline \multicolumn{3}{|c|}{ Queensland - Cape York } \\
\hline Early Man & $\mathrm{EM}$ & Rosenfeld (1981b) - tracings of engraved panels \\
\hline Early Man Shelter C & $\mathrm{EMC}$ & \multirow[t]{2}{*}{ Rosenfeld (1981b) } \\
\hline Early Man Shelter H & $\mathrm{EMH}$ & \\
\hline Emu Dreaming & $\mathrm{ED}$ & \multirow{4}{*}{$\begin{array}{l}\text { Trezise unpublished scaled illustrations, Australian Institute of Aboriginal and } \\
\text { Torres Strait Islander Studies, Canberra - all recordings checked during } \\
\text { personal fieldwork }\end{array}$} \\
\hline Death Adder Gallery & $\mathrm{DA}$ & \\
\hline Laura River & LR & \\
\hline Possum Gallery & $P G$ & \\
\hline Green Ant & GA & \multirow[t]{2}{*}{ Flood (pers. comm.) } \\
\hline Echidna Shelter & ES & \\
\hline
\end{tabular}

Queensland - Mt. Isa region

\begin{tabular}{l|l|l}
\hline Browns Creek & BC & Personal fieldwork \\
\hline Carbine Creek & CC & Morwood (1985) \\
\hline Einasleigh & E & Ron Edwards (1967)-drawing of engraved panel \\
\hline Frank Creek & FC & Personal fieldwork \\
\hline
\end{tabular}

\section{Southeast Queensland}

\begin{tabular}{l|c|l}
\hline Bundaberg & B & Rola-Wojciechowski (1983) \\
\hline Gatton & G & Quinnell (1972)-tracing of engraved panel \\
\hline
\end{tabular}

\section{Central Western Queensland}

\begin{tabular}{|l|l|}
\hline Buckland Creek 1 & BC1 \\
\hline Bull Hole & BH \\
\hline Dooloogarah 2 & D2 \\
\hline Goat Rock 1 & GR1 \\
\hline Goat Rock 2 & GR2 \\
\hline Morven & M \\
\hline Native Well 1 & NW1 \\
\hline Native Well 2 & NW2 \\
\hline Ochre Site 1 & O1 \\
\hline Paddy's Cave & PC \\
\hline Plateau 1 & P1 \\
\hline Twelve Mile Crossing & $12 \mathrm{MC}$ \\
\hline Weir 1 & W1 \\
\hline
\end{tabular}

Morwood (1979)

\section{Western Australia}

\begin{tabular}{l|c|c}
\hline Edah & Ed & Personal fieldwork \\
\cline { 1 - 2 } Kybra Site & $K$ &
\end{tabular}

southwest possibly from as far afield as Wilgie Mia in the Murchison district (McCarthy, 1939; Meagher and Ride, 1979). Classes of cultural expression other than art must have been used in boundary maintenance, as a large number of Aboriginal groups are attested in this resource-rich area west of the limit of circumcision (Anderson, 1984; Berndt, 1973; Tindale, 1974).

The engravings at the Kybra Site occurred on a series of flat tabular limestone pavements in a 
cleared and fenced paddock on private land $3 \mathrm{~km}$ from the Southern Ocean. They extended over an area approximately $75 \mathrm{~m}$ north to south and $25 \mathrm{~m}$ east to west, and included about 25 limestone blocks. The site comprised over 100 engravings, mostly bird and macropod tracks, although a star motif, single meandering lines (possibly snake or lizard tracks), and several boomerang-shaped outlines were also found. The animal track engravings were usually somewhat larger than lifesize. Large bird track engravings, presumably the prints of emus, were the most common motifs. Smaller bird tracks, perhaps of bustards and unidentified wading types, were the next most numerous. There was also a number of macropod track engravings, which included both hind and fore prints (Clarke, 1983: Figure 1).

Along with engravings at Yalgoo (Edah Station) and Yeelirrie, 420 and $680 \mathrm{~km}$ respectively north and northeast of Perth, Clarke (1983) noted that the Kybra Site appeared to extend the known range of Panaramitee style engravings (Maynard, 1979).
This paper re-examines the Kybra site in a broader context. In particular, it provides a more detailed comparison of the site with Panaramitee engravings from other sites across the continent than was undertaken by Clarke in 1983. The following questions will be addressed in this paper:

- Does the Kybra Site show similarities with other Panaramitee style engraving sites?

- Can the Discontinuous Dreaming Network Model be used to explain any similarities or differences identified between the Kybra sites and Panaramitee sites from other parts of the continent?

A comparative analysis of the Kybra site

The Panaramitee style has been represented as homogeneous at a continental level in terms of technique (pecked engravings), form (bands, thick outlines and solid figures) and motif proportions (see above). By contrast, two other defined sets of Australian rock art styles in a sequence defined by

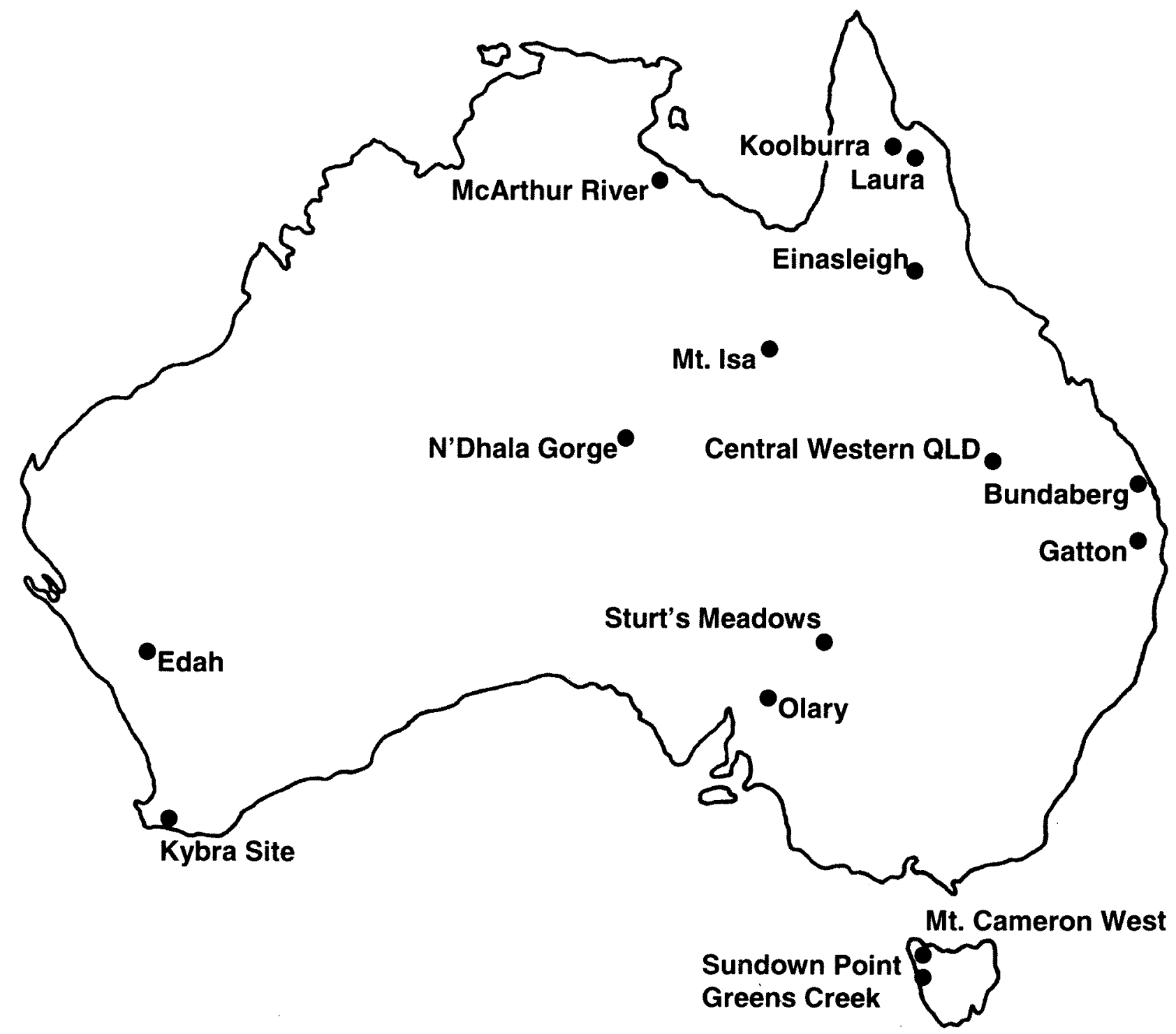

Figure 3 Map of Australia showing the Panaramitee tradition sites and regions analysed in this paper. 


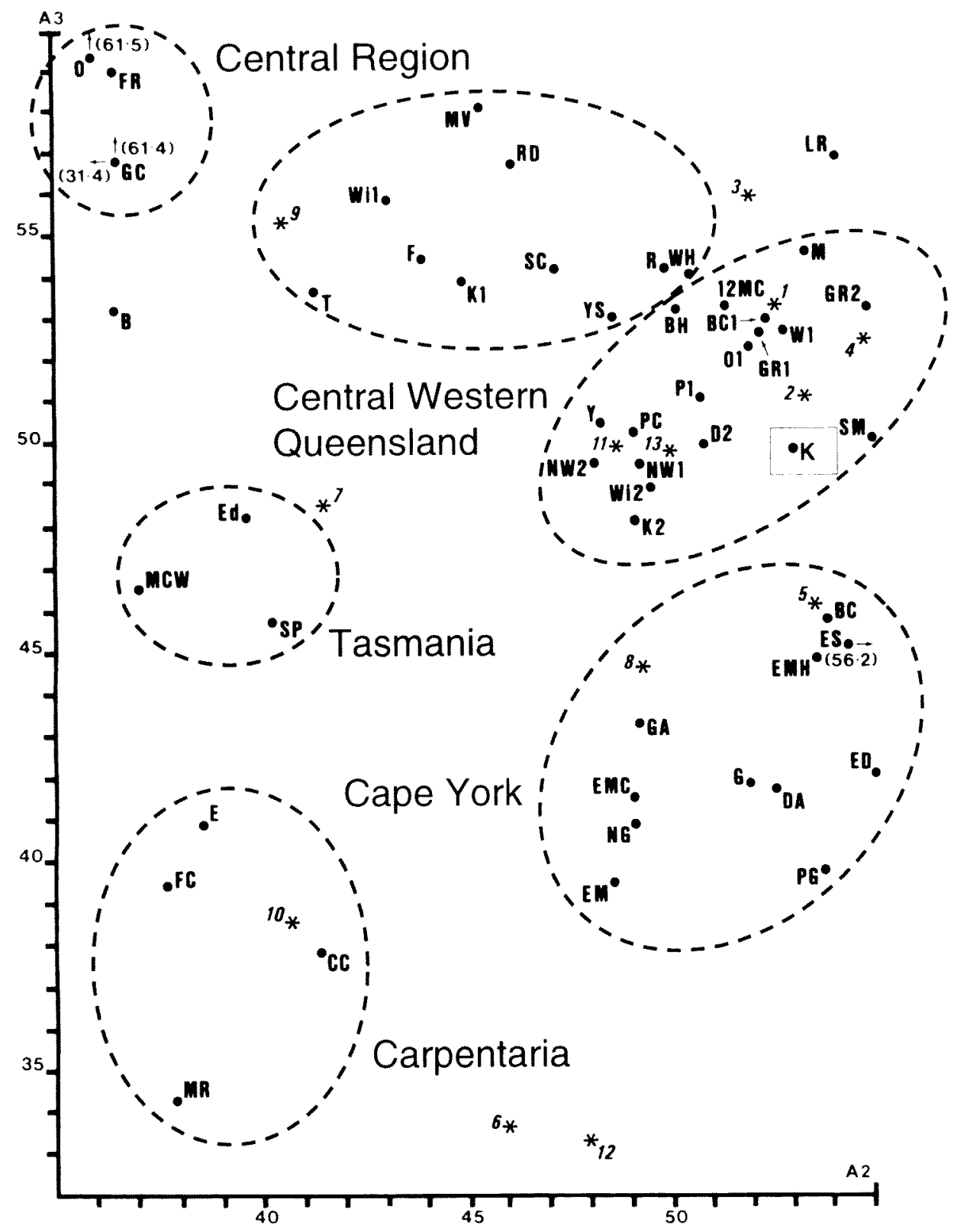

Key for Figure 4

* Sites

List of motifs
1. Macropod tracks
$\sqrt{ } L$
5. Dots/pits
10. Complex circles
2. Bird tracks $\downarrow$
6. Meandering lines/mazes $\longrightarrow \longrightarrow$
11. Crescents
3. Human footprints

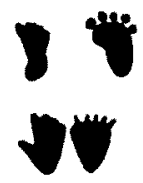
7. Simple lines
8. Complex lines $\pi \pi m$
12. Radiating lines
4. Other tracks
9. Simple circles $\bigcirc$
13. Other figuratives

(อ)

Figure 4 Correspondence analysis of Panaramitee tradition sites analysed in this paper, showing the second and third axes which account for $36.07 \%$ of the total variation. See Table 2 for site abbreviations. 
Table 3 Percentages of motifs at the Panaramitee tradition sites analysed in this paper (rounded to whole numbers). For site abbreviations, see Table 2. NB complex circles could not be determined for the central western Queensland sites (BC1 - W1 inclusive).

\section{Motifs}

Tota

\begin{tabular}{|c|c|c|c|c|c|c|c|c|c|c|c|c|c|c|}
\hline Site & $\sqrt{6}$ & $\downarrow$ & & & $\infty$ & ofer & & $\pi \mathrm{rm}$ & & (9) & $r$ & 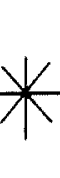 & 总 & \\
\hline FR & 1 & 12 & 0 & 0 & 0 & 1 & 0 & 0 & 73 & 1 & 12 & 0 & 0 & 127 \\
\hline $\mathrm{F}$ & 16 & 10 & 3 & 3 & 12 & 3 & 4 & 0 & 40 & 0 & 8 & 0 & 1 & 497 \\
\hline K1 & 15 & 16 & 2 & 0 & 19 & 0 & 5 & 0 & 38 & 2 & 3 & 0 & 0 & 1,579 \\
\hline $\mathrm{K} 2$ & 12 & 10 & 0 & 0 & 42 & 0 & 0 & 0 & 20 & 5 & 10 & 0 & 1 & 94 \\
\hline MV & 41 & 6 & 0 & 0 & 0 & 0 & 0 & 0 & 35 & 0 & 18 & 0 & 0 & 17 \\
\hline $\mathrm{O}$ & 0 & 15 & 4 & 0 & 0 & 0 & 0 & 0 & 81 & 0 & 0 & 0 & 0 & 26 \\
\hline $\mathrm{R}$ & 41 & 17 & 4 & 1 & 9 & 0 & 1 & 1 & 17 & 4 & 4 & 0 & 1 & 5,857 \\
\hline RD & 31 & 13 & 4 & 1 & 10 & 0 & 1 & 0 & 35 & 1 & 4 & 0 & 0 & 442 \\
\hline SC & 33 & 17 & 2 & 1 & 7 & 1 & 0 & 0 & 26 & 6 & 6 & 0 & 1 & 2,471 \\
\hline $\mathrm{T}$ & 22 & 9 & 3 & 0 & 6 & 0 & 1 & 0 & 43 & 14 & 2 & 0 & 0 & 236 \\
\hline WH & 40 & 24 & 4 & 1 & 6 & 0 & 2 & 1 & 14 & 4 & 4 & 0 & 0 & 2,246 \\
\hline Wi1 & 20 & 16 & 1 & 2 & 6 & 1 & 9 & 0 & 40 & 1 & 4 & 0 & 0 & 925 \\
\hline $\mathrm{Wi2}$ & 22 & 6 & 0 & 0 & 37 & 1 & 12 & 0 & 12 & 1 & 9 & 0 & 0 & 147 \\
\hline Y & 15 & 14 & 1 & 1 & 29 & 1 & 2 & 0 & 22 & 4 & 11 & 0 & 0 & 396 \\
\hline YS & 28 & 13 & 4 & 1 & 21 & 0 & 9 & 1 & 20 & 0 & 3 & 0 & 0 & 1,069 \\
\hline SM & 28 & 27 & 2 & 3 & 32 & 1 & 1 & 1 & 2 & 0 & 3 & 0 & 0 & 13,901 \\
\hline NG & 17 & 13 & 1 & 0 & 28 & 8 & 0 & 2 & 7 & 12 & 4 & 6 & 2 & 5,462 \\
\hline $\mathrm{GC}$ & 0 & 0 & 0 & 0 & 0 & 0 & 0 & 1 & 96 & 3 & 0 & 0 & 0 & 66 \\
\hline MCW & 0 & 2 & 0 & 0 & 16 & 2 & 9 & 1 & 44 & 22 & 4 & 0 & 0 & 404 \\
\hline $\mathrm{SP}$ & 0 & 0 & 0 & 0 & 32 & 0 & 13 & 2 & 34 & 17 & 2 & 0 & 0 & 250 \\
\hline K & 21 & 47 & 0 & 0 & 11 & 0 & 4 & 12 & 3 & 0 & 1 & 1 & 0 & 75 \\
\hline Ed & 6 & 4 & 1 & 0 & 6 & 0 & 1 & 0 & 33 & 22 & 27 & 0 & 0 & 72 \\
\hline $\mathrm{BC}$ & 27 & 7 & 0 & 0 & 51 & 1 & 3 & 2 & 2 & 3 & 2 & 1 & 1 & 359 \\
\hline $\mathrm{CC}$ & 2 & 13 & 0 & 2 & 7 & 11 & 8 & 2 & 13 & 28 & 9 & 2 & 3 & 707 \\
\hline E & 0 & 11 & 0 & 0 & 8 & 2 & 8 & 0 & 28 & 30 & 5 & 7 & 1 & 133 \\
\hline $\mathrm{FC}$ & 2 & 3 & 0 & 0 & 9 & 2 & 7 & 2 & 22 & 39 & 12 & 1 & 1 & 467 \\
\hline MR & 0 & 3 & 0 & 0 & 12 & 8 & 24 & 6 & 6 & 38 & 3 & 0 & 0 & 87 \\
\hline B & 0 & 2 & 0 & 1 & 13 & 2 & 7 & 3 & 62 & 8 & 1 & 0 & 1 & 1,283 \\
\hline G & 0 & 6 & 0 & 0 & 69 & 1 & 13 & 2 & 2 & 2 & 5 & 0 & 0 & 403 \\
\hline BC1 & 22 & 13 & 6 & 20 & 1 & 3 & 3 & 0 & 2 & 0 & 24 & 0 & 6 & 105 \\
\hline $\mathrm{BH}$ & 5 & 41 & 9 & 5 & 4 & 3 & 2 & 0 & 15 & 0 & 16 & 0 & 0 & 195 \\
\hline D2 & 1 & 3 & 0 & 6 & 0 & 0 & 0 & 0 & 0 & 0 & 0 & 0 & 90 & 143 \\
\hline GR1 & 13 & 15 & 10 & 8 & 0 & 1 & 3 & 0 & 0 & 0 & 1 & 0 & 49 & 417 \\
\hline GR2 & 13 & 58 & 7 & 3 & 2 & 0 & 1 & 1 & 0 & 0 & 0 & 0 & 15 & 93 \\
\hline M & 65 & 22 & 0 & 0 & 0 & 0 & 3 & 1 & 3 & 0 & 3 & 3 & 0 & 148 \\
\hline NW1 & 1 & 6 & 0 & 1 & 1 & 0 & 7 & 0 & 1 & 0 & 0 & 0 & 83 & 392 \\
\hline NW2 & 5 & 1 & 0 & 0 & 0 & 0 & 12 & 0 & 0 & 0 & 0 & 0 & 82 & 137 \\
\hline O1 & 25 & 35 & 2 & 3 & 0 & 0 & 10 & 3 & 1 & 0 & 4 & 1 & 16 & 285 \\
\hline PC & 5 & 29 & 3 & 3 & 0 & 0 & 19 & 3 & 0 & 0 & 3 & 1 & 34 & 237 \\
\hline $\mathrm{P} 1$ & 9 & 24 & 0 & 2 & 2 & 1 & 1 & 0 & 2 & 0 & 39 & 0 & 20 & 172 \\
\hline $12 \mathrm{MC}$ & 19 & 17 & 17 & 9 & 6 & 5 & 1 & 0 & 9 & 0 & 15 & 0 & 2 & 168 \\
\hline W1 & 10 & 21 & 12 & 14 & 6 & 2 & 2 & 0 & 2 & 0 & 18 & 0 & 13 & 297 \\
\hline DA & 0 & 19 & 0 & 0 & 58 & 5 & 11 & 3 & 0 & 1 & 3 & 0 & 0 & 64 \\
\hline EM & 3 & 30 & 0 & 0 & 20 & 20 & 14 & 2 & 2 & 2 & 5 & 2 & 0 & 120 \\
\hline EMC & 2 & 31 & 0 & 0 & 21 & 5 & 18 & 8 & 0 & 2 & 5 & 8 & 0 & 39 \\
\hline EMH & 5 & 67 & 0 & 0 & 5 & 14 & 0 & 9 & 0 & 0 & 0 & 0 & 0 & 21 \\
\hline ES & 9 & 17 & 1 & 1 & 64 & 0 & 0 & 0 & 0 & 0 & 1 & 0 & 7 & 171 \\
\hline ED & 0 & 14 & 0 & 0 & 79 & 1 & 1 & 1 & 1 & 0 & 2 & 1 & 0 & 285 \\
\hline GA & 9 & 3 & 3 & 2 & 50 & 6 & 3 & 1 & 13 & 8 & 1 & 0 & 1 & 119 \\
\hline LR & 36 & 17 & 22 & 6 & 1 & 0 & 0 & 0 & 1 & 0 & 1 & 0 & 16 & 88 \\
\hline$P G$ & 2 & 10 & 0 & 0 & 71 & 4 & 6 & 2 & 0 & 3 & 0 & 2 & 0 & 67 \\
\hline
\end{tabular}


Maynard (1979), the Simple Figurative and Complex Figurative, are more variable and spatially restricted (Maynard, 1979: Figure 4-1), and have also been argued to be more recent than the Panaramitee. Maynard (1979) stated that Panaramitee style engravings reveal a pancontinental distribution, being found in South Australia, central Australia, western New South Wales, at Ingaladdi (Yingalarri) in the Northern Territory, in the Laura area of Cape York Peninsula, the Mt. Isa region of northwestern Queensland and in Tasmania (Maynard, 1979: Figure 4-1).

The most significant feature of the sites in South Australia, central Australia and western New South Wales (referred to as the "classic sites") is a constancy in the relative proportions of motifs, where the combined totals of tracks and circles mainly comprised between about $83 \%$ and $88 \%$ of the total motifs, with other motifs only comprising between about $11 \%$ and $17 \%$. Figurative motifs other than tracks were extremely rare at these sites, constituting $0.5 \%$ or less of the total, with lizards being the most common types (Edwards, 1966, 1971; Maynard, 1979). However, pecked engravings of tracks and nonfigurative motifs found in other regions of Australia (e.g. Laura and Tasmania) do not reveal this constancy of motif proportions. Maynard observed that this was because the smaller number of engravings at the latter sites meant that not enough figures were accumulated to result in the motif proportions found at the widely distributed classic sites. However, since these peripheral sites displayed identical techniques, forms and range of motifs, they too were included in the Panaramitee (Maynard, 1979). Although not described at the time of her research, the Kybra Site appears to conform to one of Maynard's peripheral Panaramitee sites, as sample size is small.

It should be noted that the concept of the Panaramitee as a style has been debated (e.g. Bednarik, 1988, 1994, 1995; Maynard, 1988; Rosenfeld, 1991; see also Franklin, 2007). Flood (1997) prefers to use the term "tradition" to describe the Panaramitee, as it "...implies culture contact and continuity but not necessarily close similarity or uniformity" (p. 179). Use of this term is appropriate, as it covers "...long-term continuity in either individual technologies or attributes" and "a temporally ordered series of archaeological phases or cultures that show cultural similarities to each other" (Bahn, 2001: 452). This concept of "tradition" also parallels the use of the term to describe Australian stone tool technologies (e.g. the Core Tool and Scraper Tradition). "Tradition" is more appropriate than the term "style", as the latter term refers to "...a highly specific and characteristic manner of doing something..." which is "...always peculiar to a specific time and place..." (Sackett, 1977: 370), and in the case of the engraving sites analysed in this paper, there is probably chronological and spatial variation.

Like Flood (1997), I also prefer to retain the term "Panaramitee" for this tradition of rock art, as many Australian rock art researchers and archaeologists have found it a useful term (e.g. Clegg, 1988, 1992; David, 1988; David and Chant, 1995; Franklin, 1984, 1986, 1989, 1991, 2004, 2007; McDonald, 1982, 1983, 1988; Morwood, 1979, 1984, 1988, 2002; Smith, 1992). It follows the standard archaeological practice of labelling a tradition or culture after a type-site which contains an extensive and typical example of the material in question (e.g. the Mousterian after the type-site of Le Moustier).

However, it should be made clear that the label Panaramitee only refers to the manifestation of the tradition within Australia (see also Flood, 1997). As Bednarik (1995) has shown, some of the rock art of other continents also resembles the Panaramitee. This observation is made clear by the results of the blind test undertaken by Bednarik (1995), whereby eight rock art specialists were sent copies of unlabelled drawings of engravings and asked to identify where they came from. Although the engravings were all from North and South America, Africa and Europe, and the score of wrong answers was $98 \%$, there was nevertheless internal consistency in the answers provided by the specialists, who identified the engravings as being from particular sites in Australia. The results of Bednarik's test therefore tend to confirm the widespread similarities of this form of rock art within Australia, and in no way negate the use of the term Panaramitee tradition within Australia, even though there may be world-wide resemblances.

Seventy-five engraved motifs were counted at the Kybra Site during fieldwork undertaken by the author and others in December 1987 (Table 1; Figure 2). As noted above, Clarke (1983) referred to over 100 motifs at the site, a discrepancy that may be due to increased grass coverage over time, as pasture plants have grown over many of the tabular limestone blocks that make up the site and obscured engravings in many cases. Other possible reasons for the discrepancy may be that there were differences in the ways in which motifs were counted, or that Clarke only made a rough estimate of the number of engravings at the site.

The Kybra Site is dominated by engraved tracks, which constitute $68 \%$ of the motif assemblage, of which bird tracks are the most common at $47 \%$ (Table 1). Nonfigurative motifs are also very frequent, comprising $32 \%$ of the assemblage However, circles are quite rare at the site, constituting only $3 \%$ of the total motifs. The combined total of tracks and circles at the Kybra Site is therefore only $71 \%$, less than the combined totals noted by Edwards $(1966,1971)$ and Maynard 
(1979) for the classic Panaramitee sites (see above).

The following comparison will consider, first, the other Western Australian sites mentioned by Clarke (1983), and secondly, Panaramitee tradition engraving sites from across the continent. Rock engravings on Edah Station (Department of Indigenous Affairs, Site No. 5910) are located in the Murchison district near the township of Yalgoo (Figure 1). The engravings occur towards the base of a large, low granite outcrop, on a sloped surface immediately above a soak. Given the extensive size of the outcrop, the engravings only cover a small area, measuring $4.6 \mathrm{~m}$ by $2.4 \mathrm{~m}$ at the maximum extent of the panel. However, the engravings must have once been more extensive, since the top layers of granite are exfoliating, so that any engravings originally occurring may have been removed (Franklin, 2004).

There are 72 motifs at this site (Table 1). These stand out fairly clearly as white grooves against the orange-red rock surface (Franklin, 2004: Plates 13C and $14 \mathrm{~A})$. The majority of motifs are simple circles (33\% of the total) and complex circles $(22 \%$, comprising circles with dotted infill, bisecting lines and central dots, as well as concentric, barred and conjoined circles). Crescents also form a significant proportion of the total $(27 \%)$, while all other motifs - macropod and bird tracks, human footprints, pits and straight lines - only constitute small percentages. The pattern of motif frequency is therefore quite different to that found at the Kybra Site, in terms of a much larger proportion of circles of different kinds at Edah, and a smaller proportion of animal tracks.

On Yeelirrie Station, a series of about 20-30 rock engravings occur on exposed granite outcrops in the dry bed of a creek (Department of Indigenous Affairs, Site No. 10746; Department of Aboriginal Sites 1978; Figure 1). The motifs are deeply pecked and abraded, with the peck marks being up to a centimetre or more in depth. They are very heavily patinated. The range of motifs includes macropod and bird tracks (some within circles), two parallel lines of dots, circles, a human footprint and possibly a human stick figure. The macropod tracks include front and hind feet as well as tail-prints. This range of motifs fits more comfortably with that observed at the Kybra Site than do the engravings at Edah. A detailed count of motif types is not available for the engravings at Yeelirrie.

Franklin $(2004,2007)$ carried out a detailed multivariate investigation of 51 Panaramitee tradition engraving sites across Australia (Table 2, Figure 3), using correspondence analysis and cluster analysis of motif counts. Both the Kybra Site and Edah were included in the sample of sites investigated. The analyses compared sites in terms of a master typology of some 13 motif types that was established in order to provide a basis for comparison. Counts were derived from both published and unpublished sources as well as original data (Tables 2 and 3). Both the Kybra Site and Edah only contain 8 of the 13 motif types (Tables 1 and 3; see Franklin, 2004, 2007 for further detail on the methods employed here).

The results indicated that there was inter-regional variation in terms of differing emphases on motifs or combinations of motifs within an overall restricted range across the continent (Figures 4 and $5)$. Five major groups were identified in the analyses (Figures 4 and 5; see also Franklin 2004: Figs. $3: 12$ and 3:14), indicating a high degree of regionality and resulting in the definition of five rock engraving regions, labelled Central, Cape York Peninsula, Carpentaria, Tasmania and Central Western Queensland (Table 4).

However, it was also found that some sites were similar to more than one of the regions isolated in the multivariate analyses. The Kybra Site was one of these, showing similarities with sites in both the Cape York Region and Central Western Queensland regions (Figures 4 and 5, Table 4 ). These included a similar dominance of bird tracks in the case of the former region, plus similar proportions of pits and complex lines, and in the case of Central Western Queensland, a similar emphasis on both macropod and bird tracks.

By contrast, the site on Edah Station grouped with those of the Carpentaria Region (comprising sites from Mt. Isa, Einasleigh and the McArthur River, see Figures 3-5) due to a shared emphasis on simple and complex circles and a decreased proportion of animal tracks (Table 3 ).

The multivariate analyses therefore found that both the Kybra Site and Edah grouped with engraving sites on the other side of the continent (Figures 4 and 5). They did not group with each other, as might be expected due to their much closer geographic proximity. This result confirmed the widespread similarity of the rock engraving sites that have been referred to the Panaramitee tradition, and that were included in the multivariate investigation (Franklin, 2004, 2007).

These findings fit well with the widespread contacts forged by Dreaming tracks that are predicted by the Discontinuous Dreaming Network Model (Franklin, 2004, 2007, see above), and suggested by the trade and other social networks that sometimes spanned the continent. The regionality identified in the multivariate analyses can be explained in terms of the deployment of motifs that are relevant to the particular parts of Dreaming tracks on which people reside or to which they own the ceremonial rights. The links between rock engraving sites and Dreaming tracks envisaged in the Model are also supported in Western Australia by some mythological details that are available for one of the engraving sites 
Table 4 Regional groups of Panaramitee tradition sites identified in the multivariate analyses. The sites in italics show similarities with the Regional group indicated, although they are distant geographically, indicating the widespread nature of the similarities between the engraving sites analysed in this paper.

\begin{tabular}{|c|c|c|c|}
\hline Name of Region & Sites & General Description & Dominant Motifs \\
\hline Central & $\begin{array}{l}\text { All South and } \\
\text { central Australian } \\
\text { sites }\end{array}$ & $\begin{array}{l}\text { Single motifs do not tend to dominate } \\
\text { sites to such an extent as is the case in } \\
\text { other Regions; sites have smaller } \\
\text { proportions of a range of motits. } \\
\text { Characteristic motifs are all kinds of } \\
\text { tracks (but esp. macropod and bird), } \\
\text { dots, simple circles, some complex } \\
\text { circles, simple lines and crescents }\end{array}$ & \\
\hline Cape York & $\begin{array}{l}\text { Early Man } \\
\text { Early Man C \& H } \\
\text { Emu Dreaming } \\
\text { Possum Gallery } \\
\text { Death Adder } \\
\text { Green Ant } \\
\text { Echidna Shelter } \\
\text { Gatton }\end{array}$ & $\begin{array}{l}\text { Many sites emphasise pits; mazes, } \\
\text { and simple, complex and radiating } \\
\text { lines are also common. Macropod } \\
\text { tracks are rare, although bird tracks } \\
\text { may be quite common at some sites. } \\
\text { Other tracks virtually do not occur. } \\
\text { All circles are infrequent. }\end{array}$ & \\
\hline Carpentaria & $\begin{array}{l}\text { Frank Creek } \\
\text { Carbine Creek } \\
\text { McArthur River } \\
\text { Einasleigh } \\
\text { Edah }\end{array}$ & $\begin{array}{l}\text { Marked emphasis on complex circles, } \\
\text { and to a lesser extent simple circles; } \\
\text { radiating lines and mazes at most } \\
\text { sites; tracks not common, but of them } \\
\text { bird tracks are most frequent. }\end{array}$ & \\
\hline Tasmania & $\begin{array}{l}\text { Mt. Cameron West } \\
\text { Sundown Point } \\
\text { Greens Creek }\end{array}$ & $\begin{array}{l}\text { Circles dominate, simple circles being } \\
\text { more common than complex circles. } \\
\text { Dots and simple lines are also quite } \\
\text { common. All other motifs are } \\
\text { infrequent or currently unknown. }\end{array}$ & \\
\hline $\begin{array}{l}\text { Central Western } \\
\text { Queensland }\end{array}$ & $\begin{array}{l}\text { Bull Hole; Morven } \\
\text { Weir 1, Twelve } \\
\text { Miles Crossing; } \\
\text { Goat Rock } 1 \& 2 \\
\text { Buckland Creek } 1 \\
\text { Ochre Site 1; Native } \\
\text { Well } 1 \text { \& } 2 \text { Plateau } \\
\text { 1; Paddy's Cave; } \\
\text { Dooloogarah } 2\end{array}$ & $\begin{array}{l}\text { Tracks of all kinds are common. } \\
\text { Human footprints and "other" tracks } \\
\text { are more common here than } \\
\text { anywhere else. Crescents are also } \\
\text { common; circles are not. Marked } \\
\text { emphasis on vulvas at some sites. }\end{array}$ & \\
\hline
\end{tabular}

discussed in this paper, Yeelirrie (Figure 1), where an Aboriginal informant indicated their manufacture by the Wati Kutjara Dreaming beings (Tindale, 1936) and related the account of their journey along the edge of the creek at the site (Department of Aboriginal Sites, Western Australian Museum, 1978).

In relation to the antiquity of the Kybra Site, Clarke (1983) found it difficult to explain how the engravings could have survived for an extended period of time on such a weatherable rock type (algal limestone) in such a hostile, high-rainfall area when, based on Maynard's (1979) sequence, they should be of considerable age (i.e., late Pleistocene). Clarke therefore postulated a period of burial beneath dune sand, which protected the engravings, and more recent re-exposure. However, he subsequently argued (Clarke, 1989) that the more recent dates of about 1,000 years for Panaramitee tradition engravings at Karolta 1 in the Olary Province of South Australia (Dorn et al., 1988; Nobbs and Dorn, 1988) fit well with a recent origin for the Kybra Site 


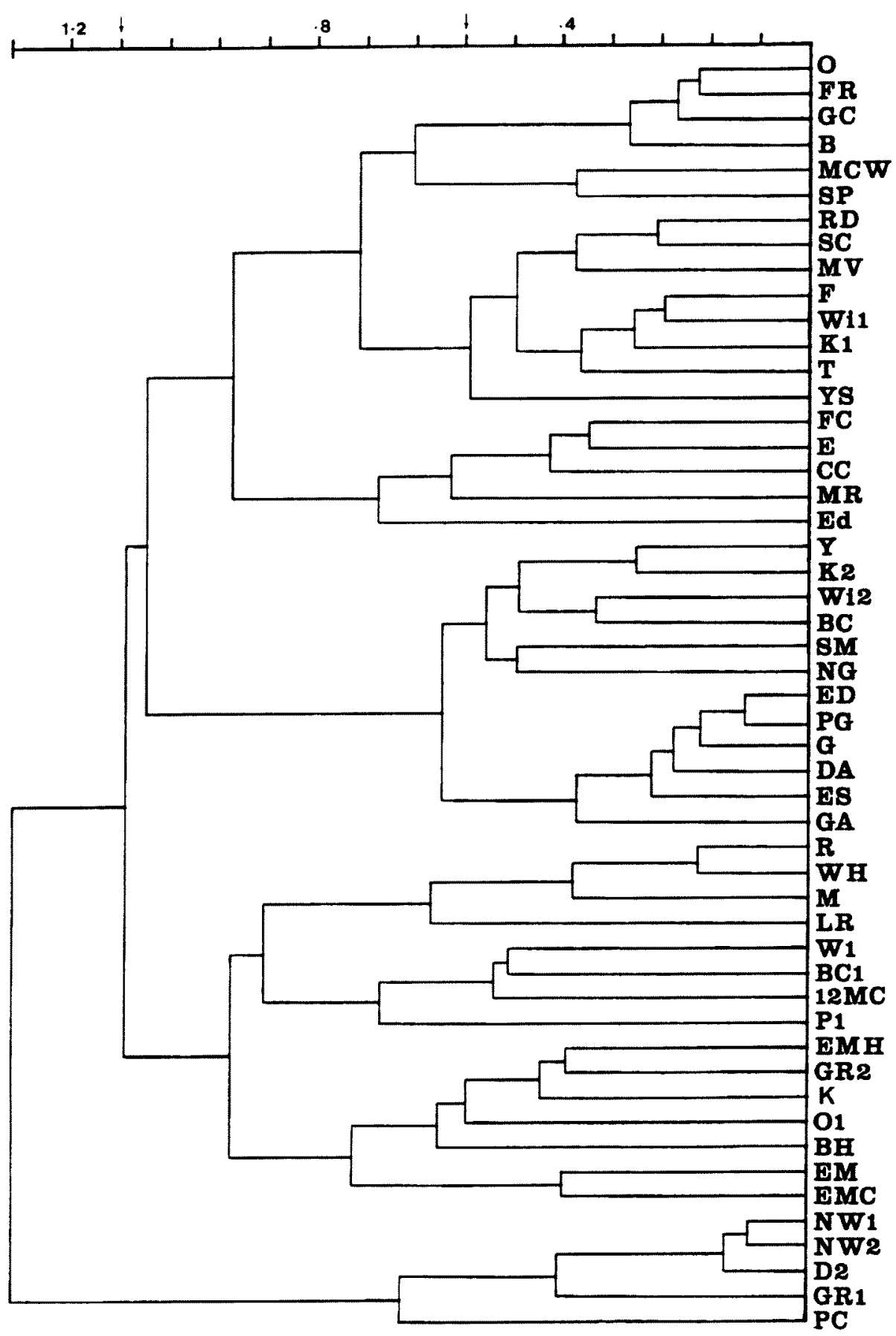

Figure 5 Cluster analysis of Panaramitee tradition sites analysed in this paper. See Table 2 for site abbreviations.

(but see Franklin (2004) for a review of the problems associated with the cation-ratio dates for Karolta 1). Furthermore, a relatively recent date for the engravings, the similarities between the site and engravings in the Cape York Peninsula Region (Figures 4 and 5), and the considerable antiquity for some Panaramitee tradition sites, such as Early Man, also in Cape York Peninsula (Rosenfeld, 1981a, see above), are also consistent with the chronological persistence of Panaramitee motif types envisaged in the Discontinuous Dreaming Network Model. The possible continuation of the Panaramitee tradition over a long period of time is allowed for by the extreme simplicity of its motif types, whereby the "discontinuous" meaning ranges of the motifs are able to change over time, while there may not necessarily be any change in the morphology of the motifs themselves.

\section{CONCLUSIONS}

This paper has presented a comparison of a series of rock engravings from the Kybra Site in far southwestern Australia, originally described by Clarke (1983), with other Panaramitee tradition engravings found both within Western Australia, and from 
other parts of the continent (see also Franklin, 2004, 2007). This comparison has been undertaken with a larger sample of sites than was available to Clarke. It was found that engravings at the Kybra Site grouped with sites from both Cape York Peninsula and Central Western Queensland, on the other side of the continent. Similarly, rock engravings at Edah Station were found to be similar to sites in the Carpentaria Region, again at a considerable geographic distance. These two engraving sites are therefore more different to each other than they are to sites widely distributed away from them. It was argued that both of these findings were consistent with the tenets of the Discontinuous Dreaming Network Model (Franklin, 2004, 2007).

I anticipate that the pattern of engraved motifs at the Kybra Site will be confirmed by further detailed investigations, where planned excavations (R.G. Gunn, pers. comm.) are expected to uncover more engravings and perhaps settle any inter-recorder discrepancies in motif numbers caused by increased grass cover over time.

\section{ACKNOWLEDGEMENTS}

I thank Rob Reynolds, of the Department of Aboriginal Sites, Western Australian Museum (now Department of Indigenous Affairs), Dr. Phillip Habgood, for assistance in the field at the Kybra Site, photography and polythene tracings of the engravings. The Department of Aboriginal Sites also provided information about engraving sites in Western Australia, and general logistical support.

\section{REFERENCES}

Anderson, C. and Dussart, F. (1988). Dreamings in acrylic: Western desert art. In P. Sutton (ed.), Dreamings: The Art of Aboriginal Australia, pp. 89142. Penguin, Melbourne.

Anderson, J. (1984). Between Plateau and Plain: Flexible Responses to Varied Environments in Southwestern Australia. Occasional Papers in Prehistory 4. Department of Prehistory, Research School of Pacific Studies, Australian National University, Canberra.

Bahn, P.G. (ed.). (2001). The Penguin Archaeology Guide. Penguin Books, Ringwood, Victoria.

Bednarik, R.G. (1988). Comment on F.D. McCarthy, "Rock art sequences: A matter of clarification". Rock Art Research 5: 22-24.

Bednarik, R.G. (1994). Rock art as a cultural determinant. AURA Newsletter 11(2): 9-12.

Bednarik, R.G. (1995). Taking the style out of the Panaramitee style. AURA Newsletter 12(1): 1-5.

Berndt, R.M. (1973). Aborigines of southwestern Australia: the past and the present. Journal of the Royal Society of Western Australia 56: 50-54.

Chatwin, B. (1987). The Songlines. Picador, London.

Clarke, J. (1983). An Aboriginal engraving site in the south-west of Western Australia. Records of the Western Australian Museum 11: 63-67.

Clarke, J. (1989). Comment on M.F. Nobbs and R.I. Dorn, "Age determinations for rock varnish formation within petroglyphs: Cation-ratio dating of 24 motifs from the Olary region, South Australia". Rock Art Research 6:63-65.

Clegg, J. (1988). Comment on F.D. McCarthy, "Rock art sequences: a matter of clarification". Rock Art Research 5: 30.

Clegg, J. (1992). Rules of similarity in Panaramitee engraving sites. In J. McDonald, J., and Haskovec, I. P. (eds.), State of the Art: Regional rock art studies in Australia and Melanesia. Proceedings of Symposium $C_{1}$ "Rock Art Studies in Australia and Oceania" and Symposium D, "The Rock Art of Northern Australia" of the First AURA Congress, held in Darwin in 1988, pp. 32-38. Occasional AURA Publication No. 6. Australian Rock Art Research Association, Melbourne.

David, B. (1988). Comment on F.D. McCarthy, "Rock art sequences: A matter of clarification". Rock Art Research 5: 22-24.

David, B. (2002). Landscapes, Rock-Art and the Dreaming: An Archaeology of Preunderstanding. Leicester University Press, London.

David, B. and Chant, D. (1995). Rock Art and Regionalisation in North Queensland Prehistory. Memoirs of the Queensland Museum 37(2).

Department of Aboriginal Sites, Western Australian Museum. (1978). A Survey for Aboriginal Sites, Yeelirrie Uranium Project. Unpublished report, Western Mining Corporation.

Dorn, R.I., Nobbs, M. and Cahill, T.A. (1988). Cationratio dating of rock-engravings from the Olary Province of arid South Australia. Antiquity 62: 681689.

Dortch, C.E. (1976). Two engraved stone plaques of late Pleistocene age from Devil's Lair, Western Australia. Archaeology and Physical Anthropology in Oceania 11: 32-44.

Dortch, C.E. (1980). A possible pendant of marl from Devil's Lair, Western Australia. Records of the Western Australian Museum 8: 401-403.

Edwards, R. (1966). Comparative study of rock engravings in South and Central Australia. Transactions of the Royal Society of South Australia 90: 33-38.

Edwards, R. (1971). Art and Aboriginal prehistory. In D.J. Mulvaney and J. Golson (eds), Aboriginal Man and Environment in Australia, pp. 356-367. Australian National University Press, Canberra.

Edwards, R. (1967). Cave art in the Newcastle Ranges. Northern Folk 18: 6-7.

Elkin, A.P. (1934). Cult-totemism and mythology in northern South Australia. Oceania 5: 171-192.

Flood, J.M. (1997). Rock Art of the Dreamtime: Images of Ancient Australia. Harper Collins, Sydney.

Franklin, N.R. (1984). Of !Macropods and !Men: An Analysis of the Simple Figurative Styles. B.A. (Hons) Thesis, Department of Anthropology, University of Sydney. 
Franklin, N.R. (1986). Stochastic vs. emblemic: an archaeologically useful method for the analysis of style in Australian rock art. Rock Art Research 3:121140.

Franklin, N.R. (1989). Research with style: a case study from Australian rock art. In Shennan, S. J. (ed.), Archaeological Approaches to Cultural Identity, pp. 278-290. Unwin Hyman, London.

Franklin, N.R. (1991). Explorations of the Panaramitee style. In Bahn, P. and Rosenfeld, A. (eds.), Rock Art and Prehistory: Papers Presented to Symposium $G$ of the AURA Congress, Darwin 1988, pp. 120-135. Oxbow Books, Oxford.

Franklin, N.R. (2004). Explorations of Variability in Australian Prehistoric Rock Engravings. BAR International Series 1318. British Archaeological Reports: Oxford.

Franklin, N.R. (2007). Discontinuous Dreaming Networks: analyses of variability in Australian prehistoric petroglyphs. Rock Art Research 24: 79-103.

Gunn, R.G. (1981). The Petroglyphs of Sundown Point, North-West Tasmania: Some Observations and Recommendations. Unpublished report, Tasmanian National Parks and Wildlife Service, Hobart.

Gunn, R.G. (1997). Rock art, occupation and myth: The correspondence of symbolic and archaeological sites within Arrernte rock art complexes of central Australia. Rock Art Research 14: 125-136.

Gunn, R.G. (2003). Arrernte rock-art: interpreting physical permanence in a changing social landscape. Australian Aboriginal Studies No. 1: 52-73.

Haglund, L. (1975). Survey of Sites Significant to Aborigines, McArthur River Region, Northern Territory. Unpublished report, Dames and Moore for Mimets Development Pty. Ltd.

Hallam, S.J. (1971). Roof markings in the "Orchestra Shell" Cave, Wanneroo, near Perth, Western Australia. Mankind 8: 90-103.

Hallam, S.J. (1972). An archaeological survey of the Perth area, Western Australia: a progress report on art and artefacts, dates and demography. Australian Institute of Aboriginal Studies Newsletter 3: 11-19.

Hallam, S.J. (1974a). Excavations in the Orchestra Shell Cave, Wanneroo, Western Australia. Part 1: ethnographic and environmental background. Archaeology and Physical Anthropology in Oceania 9: 66-84.

Hallam, S.J. (1974b). Excavations in the Orchestra Shell Cave, Wanneroo, Western Australia. Part 2: archaeology. Archaeology and Physical Anthropology in Oceania 9: 134-155.

Hallam, S.J. (1979). Fire and Hearth: A Study of Aboriginal Usage and European Usurpation in Southwestern Australia. Australian Institute of Aboriginal Studies, Canberra.

Layton, R. (1992). Australian Rock Art: A New Synthesis. Cambridge University Press, Cambridge.

Maynard, L. (1988). Comment on F.D. McCarthy, "Rock art sequences: A matter of clarification". Rock Art Research 5: 30.

Maynard, L. (1979). The archaeology of Australian Aboriginal art. In Mead, S. M. (ed.), Exploring the
Visual Art of Oceania, pp. 83-110. University Press of Hawaii: Honolulu.

McCarthy, F.D. (1939). "Trade" in Aboriginal Australia, and "trade" relationships with Torres Strait, New Guinea and Malaya. Oceania 9: 405-438; Oceania 10: 80-104, 171-195.

McCarthy, F.D. (1969). The Rock Engravings of $M t$. Cameron West, North-West Tasmania. Unpublished report, Australian Institute of Aboriginal Studies, Canberra, and Tasmanian Museum and Art Gallery, Hobart.

McDonald, J. (1982). On the Write Track. B.A. (hons) thesis, Department of Anthropology, University of Sydney.

McDonald, J. (1983). The identification of species in a Panaramitee style engraving site. In Smith M. (ed.), Archaeology at ANZAAS 1983, pp. 236-272. Western Australian Museum, Perth.

McDonald, J. (1988). Comment on F.D. McCarthy, "Rock Art sequences: A matter of clarification". Rock Art Research 5: 28-30.

Meagher, S.J., and Ride, W.D.L. (1979). Use of natural resources by the Aborigines of south-western Australia. In R.M. Berndt and C.H. Berndt (eds), Aborigines of the West: Their Past and Their Present, pp. 66-80. University of Western Australia Press, Perth.

Merrilees, D., Dix, W.C., Hallam, S.J., Douglas, W.H. and Berndt, R.M. (1973). Aboriginal man in southwestern Australia. Journal of the Royal Society of Western Australia 56: 44-55.

Morphy, H. (1983). "Now you understand" - an analysis of the way Yolngu have used sacred knowledge to retain their autonomy. In Peterson, N., and Langton, M. (eds.), Aborigines, Land and Land Rights, pp. 110-133. Australian Institute of Aboriginal Studies, Canberra.

Morse, K. (1984). First record of painted Aboriginal rock art in a south-western Australian limestone cave. Records of the Western Australian Museum 11: 197199.

Morwood, M.J. (1979). Art and Stone: Towards a Prehistory of Central Western Queensland. Ph.D. thesis, Department of Prehistory and Anthropology, Australian National University.

Morwood, M.J. (1984). The prehistory of the Central Queensland Highlands. In Wendorf, F. and Close, A. E. (eds.), Advances in World Archaeology, pp. 325379. Academic Press: New York.

Morwood, M.J. (1985). Facts and figures: Notes on rock art in the Mt. Isa area, northwestern Queensland. Rock Art Research 2: 140-145.

Morwood, M.J. (1988). Comment on F.D. McCarthy, "Rock art sequences: A matter of clarification". Rock Art Research 5: 32-33.

Morwood, M.J. (2002). Visions from the Past: The Archaeology of Australian Aboriginal Art. Allen and Unwin, Sydney.

Moyle, R. (1983). Songs, ceremonies and sites: The Agharringa case. In N. Peterson and M. Langton (eds.), Aborigines, Land and Land Rights, pp. 66-93. Australian Institute of Aboriginal Studies, Canberra. 
Munn, N.D. (1966). Visual categories: An approach to the study of representational systems. American Anthropologist 68: 936-950.

Munn, N.D. (1973). Walbiri Iconography: Graphic Representation and Cultural Symbolism in a Central Australian Society. Cornell University Press, London.

Nobbs, M.F. (1984). Rock art in Olary Province, South Australia. Rock Art Research 1: 91-118.

Nobbs, M.F. and Dorn, R.I. (1988). Pleistocene age determinations for rock varnish formation within petroglyphs: cation-ratio dating of 24 motifs from the Olary region, South Australia. Rock Art Research 5: 108-144.

Preiss, K.A. (1962). Aboriginal rock carvings and paintings at "The Canyon", Flinders Ranges, South Australia. The South Australian Naturalist 39: 5-12.

Quinnell, M.C. (1972). Aboriginal rock engravings near Rocky Scrub Creek, Junction View, southeast Queensland: Tryon's Pigeon Creek site re-recorded. Memoirs of the Queensland Museum 16: 215-221.

Rola-Wojciechowski, C. (1983). "A Bit of Bundy": The 'Bundaberg' Engraving Site. B.A. (hons) thesis, Department of Archaeology and Palaeoanthropology, University of New England, Armidale, N.S.W.

Rosenfeld, A. (1981a). Excavations at the Early Man Shelter. In Rosenfeld, A., Horton, D. and Winter, J. (eds), Early Man in North Queensland: Art and Archaeology in the Laura Area, pp. 5-34. Terra Australis Series No. 6. Australian National University: Canberra.

Rosenfeld, A. (1981b). Rock engravings in the Laura area. In Rosenfeld, A., Horton, D. and Winter, J (eds), Early Man in North Queensland: Art and Archaeology in the Laura Area, pp. 50-89. Terra Australis Series No. 6. Australian National University, Canberra.

Rosenfeld, A. (1991). Panaramitee: Dead or alive? In Bahn, P. and Rosenfeld, A. (eds.), Rock Art and Prehistory: Papers Presented to Symposium $G$ of the AURA Congress, Darwin 1988, pp. 136-144. Oxbow Books, Oxford.
Ross, J. (1997). Painted Relationships: An Archaeological Analysis of a Distinctive Anthropomorphic Rock Art Motif in Northwest Central Queensland. BA (Hons) thesis, Department of Archaeology and Palaeoanthropology, University of New England, Armidale.

Sackett, J.R. (1977). The meaning of style in archaeology: A general model. American Antiquity 42: 369-380.

Serventy, V.N. (1952). Cave paintings near York and Hyden. The Western Australian Naturalist 3: 121-130.

Smith, C. (1992). Colonising with style: Reviewing the nexus between rock art, territoriality and the colonisation and occupation of Sahul. Australian Archaeology 34: 34-42.

Spencer, B. and Gillen, F.J. (1938). The Native Tribes of Central Australia. Macmillan and Co: London.

Stockton, J. (1977). Site Report: Greens Creek Aboriginal Engraving Site. Tasmanian National Parks and Wildlife Service Occasional Paper No. 1: Hobart.

Strehlow, T.G.H. (1978). Central Australian Religion: Personal Monototemism in a Polytotemic Community. Australian Association for the Study of Religions: Adelaide.

Sutton, P. (1988). Dreamings: The Art of Aboriginal Australia. (Exhibition catalogue). Penguin: Melbourne.

Sutton, P. (1990). The pulsating heart: Large scale cultural and demographic processes in Aboriginal Australia. In B. Meehan and N. White (eds), Hunter-Gatherer Demography: Past and Present, pp. 71-80. Oceania Monograph 39. University of Sydney: Sydney.

Tindale, N.B. (1936). Legend of the Wati Kutjara. Oceania 7: 169-185.

Tindale, N.B. (1974). Aboriginal Tribes of Australia. Australian National University Press: Canberra.

Webb, E. and Gunn, R.G. (2004). Re-recording culturally significant Aboriginal sites in south-western Australia as a guide to Noongar usage of the region in the past. Rock Art Research 21: 93-97. 